\title{
The Foreign NGOs Management Law: A Compendium
}

\section{Ivan Franceschini, Elisa Nesossi}

Recently, people from the State Security who had summoned me to 'have a tea' said to me: 'Us from the State Security are still quite civilised, but with this coming law that will regulate NGOs you will have to deal with the Public Security [i.e. the police]. You have to understand that their work methods are rather savage.' Actually, this was also a pressure of kind, you can read it as some sort of well-intentioned warning. (Interview with a Chinese labour activist, Shenzhen, June 2015)

On 1 January 2017, the highly controversial Law on the Management of Foreign NGOs' Activities within Mainland China entered into force. As defined in Article 1, the Law was introduced with the aim of 'standardising and guiding all the activities carried out by overseas NGOs within China, and protecting their rights and interests.' From January 2017, those foreign NGOs that have been operating in the People's Republic of China in a legal limbo are required to act according to the principles established by this Law. Although some scholars have argued that the Law can be interpreted as a positive development in China's process of legal development and acceptance of international standards (Sapio 2016), we fail to see how this can be the case (see also the Forum on pp. 68-73 in the present book). At this stage it appears to us that the limits imposed by the Law on the practice of foreign NGOs significantly outweigh its alleged benefits. A number of provisions within the Law are extremely vague and urgently require further explanation by the relevant authorities. Still, on this matter we are unable to share the optimism of longtime observer of Chinese civil society Shawn Shieh who, in a valuable exegesis of the Law that appeared earlier on his personal blog, noted that some flexibility may be allowed in the implementation phase (Shieh 2016). Here below we offer our short analysis of the legislation in the form of FAQs to explain its scope and significance. For the translation into English of the contents of the Law, we wish to acknowledge our debt to the excellent version that appeared on China Law Translate (China Law Translate 2016).

\section{What is an NGO and what kind of activities fall within the scope of the Law on the Management of Foreign NGOs' Activities within Mainland China?}

The Law broadly defines NGO as 'non-profit, non-governmental, social organisations lawfully established outside Mainland China, such as foundations, social groups, and think tank organisations' (Art. 2) that can operate in fields such as 'economics, education, science and technology, culture, health, sports, and environmental protection, and in areas such as poverty alleviation and disaster relief' (Art. 3). In carrying out their activities, these organisations are required to abide by Chinese laws, and not to endanger China's national unity, security or ethnic solidarity, as well as not to harm China's national interests, the common good of the society and the lawful rights and interests of citizens, legal persons, and other organisations (Art. 5). Furthermore, they must not engage in or fund for-profit activities, political or religious activities (Art. $5)$. 


\section{Be aware that:}

The range of activities NGOs can engage in, as listed in Articles 3 and 5, exclude issues that may be deemed politically sensitive, like work for the protection of labour rights and human rights (in particular civil and political rights). Article 5 is particularly vague and potentially problematic. Firstly, the meaning of 'political activity' remains unclear. In fact, the specific work in the allowed fields of operation for foreign NGOs as well as numerous policies encouraging charity and volunteer services are political at some level, and as such, might be excluded from the protection of the Law. Secondly, while it is reasonable to expect that a foreign NGO would not violate China's key national interests like national security, national unity and ethnic unity, it is important to understand the context in which these terms are phrased within Chinese law and how they may be broadly applied to incriminate a wide range of activities within society. Indeed in recent years, there have been numerous examples of NGO workers and activists having been incriminated under the existing criminal laws for endangering China's national security and interests, and in the future, in view of this Law, these circumstances might well extend to foreign NGOs. Thirdly, expressions like 'ethnic solidarity' and 'the common good of society' remain extremely vague and easily resonate with crimes concerning the disruption of public order frequently used to incriminate various categories of citizens who are considered a potential threat to social stability.

\section{Do foreign universities fall within the reach of this law?}

Article 53 of the Law states that 'where foreign schools, hospitals, natural science and engineering technology research institutions or academic organisations carry out exchanges or co-operation with Mainland Chinese schools, hospitals, natural science and engineering technology research institutions or academic organisations, it is handled according to the relevant national provisions, unless these activities violate the principles listed in Article 5.' This provision-which was inserted only in the final version of the Law and is one of the very few concessions made by the legislators to the critics-indicates that certain forms of educational exchange could be exempted from the registration requirements imposed on foreign NGOs, and that other laws should govern these kinds of activities instead.

\section{Be aware that:}

Much clarification is still needed in relation to what constitutes 'exchanges' and 'co-operation'. As some commentators have mentioned already, it is unclear whether exchanges and co-operation may include programmes between foreign schools and Chinese entities which do not operate schools (for example, third party providers of abroad programs or student internships), and unilateral programs of foreign schools (e.g., a faculty-led shortterm summer program that is organised without affiliation with any Chinese partner). It is also unclear whether a foreign university that goes to China to recruit, or to meet with its alumni, is required to either register as a representative office of a foreign NGO or work with a Chinese co-operative body and secure an approval and record filing for temporary activities from relevant Chinese authorities.

\section{What are the organs in charge of the registration and supervision of foreign NGOs?}

According to the Law, the Ministry of Public Security (MPS) and the provincial public security bureaus (PSBs) are in charge of the registration of foreign NGOs carrying out activities within Mainland China (Art. 6). The PSBs at the county level or above are required to supervise and manage the activities of foreign NGOs and to provide services for their activities (Art. 7) (note that the Law refers to public security departments 
as 'registration and management organs'). In order to register with the public security authorities and establish a representative office, foreign NGOs should receive the consent of Professional Supervisory Units established under the State Council (Arts. 6 \& 11). Once registered, they will be supervised first by the PSBs, then by a Professional Supervisory Unit at the local government level and by any other supervisory authorities responsible for national security, finance, foreign affairs, customs or tax (Art. 43).

\section{Be aware that:}

Foreign NGOs' supervision by the public security authorities is one of the most problematic aspects of the legislation. Currently, Chinese NGOs are supposed to register with the Ministry of Civil Affairs, but most of them-especially those that work in politically sensitive areas-are in fact refused registration and therefore are informally supervised by the State Security. Very few foreign NGOs are registered within China and, given their unclear legal status, their activities are informally monitored through their local partners. Giving control to the public security (rather than the Ministry of Civil Affairs) reflects the Law's emphasis on security, rather than a willingness to facilitate meaningful cooperation. It signals that, according to Chinese authorities, foreign NGOs have the potential to threaten social stability and security and, for this reason, they should be kept under control by one of the most politically powerful ministries within China. It remains to be seen whether the $M P S-$ which lacks any relevant experience in managing civil society organisations-actually has the capacity to manage NGOs.

\section{How to register a representative office in China?}

In order to carry out any activity in Mainland China, foreign NGOs should register and establish a representative office. The Law sets out the following five requirements that a foreign NGO should satisfy in order to register and establish a representative office within China: a) it should be legally established outside of Mainland China; b) it should be able to independently bear civil liability; c) the objectives and scope of activities defined in its organisational charter should be beneficial to the development of social welfare; d) it should have continuously carried out substantive activities outside of Mainland China for two or more years; e) other requirements provided by other laws and regulations (Art. 10). A foreign NGO that meets the above criteria should submit an application for registration within thirty days after having received consent by a Professional Supervisory Unit listed in a directory published by the public security organs (Arts. 11, 12). The application should include the following materials: a) a written application; b) supporting documents and materials certifying that the NGO complies with the requirement outlined in Art. 10; c) proof of identity, resumé and materials or attestations showing proof of no criminal record for the proposed chief representative; d) materials showing the proposed premises for the representative office; e) materials showing the sources of capital; f) documents of consent from the professional supervisory unit; g) other documents and materials required by law or by administrative regulations. If the registration is granted, the foreign NGO representative office will obtain a registration certificate that it will use to register for taxes, get an official seal and establish an account at a bank in Mainland China (Art. 13).

\section{Be aware that:}

First, some of the criteria included in Article 10 are extremely vague and may easily exclude some foreign NGOs from the possibility of registering within Mainland China. Indeed, it remains unclear according to which standards an activity can be deemed 'beneficial to the development of social welfare' and what the 
'other requirements provided by other laws and regulations' could be. Second, the Law does not specify whether a foreign NGO has the right to appeal decisions by the public security authorities and Professional Supervisory Units if registration is not granted. Finally, foreign NGOs are supposed to choose a local Professional Supervisory Unit from a list published by the public security organs 'together with the relevant departments' (Art. 11). This will clearly limit their choices and introduce an additional layer of supervision and control that will further restrict their ability to operate in China.

\section{Is it possible to operate without a representative office?}

Unregistered foreign NGOs that wish to conduct temporary activities within China should legally file a record (Art. 9). Foreign NGOs that have not registered and established representative offices or filed a record to carry out temporary activities are not entitled to carry out activities within Mainland China, and must not entrust or fund, or covertly entrust or fund, any unit or individual in Mainland China to carry out activities within the country (Art. 9). Temporary activities can be carried out only in co-operation with state organs, mass organisations, public institutions, or social organisations (Art. 16). It will be the Chinese partner unit who will have to file with the public security organs for the proposed activity at least fifteen days before activities are carried out (except for emergency situations) (Art. 17). The Law provides that 'temporary activities' cannot last for more than one year and that where 'there is truly a need to extend the period', a new filing shall be made (Art. 17). Beside this, the law clearly states that 'units and individuals in Mainland China must not accept retention, funding, agency, or covert agency to carry out foreign NGOs' activities in Mainland China, from foreign NGOs that have not registered a representative office or filed to carry out temporary activities' (Art. $32)$.

\section{Be aware that:}

This process entails the establishment of a closer relationship between the Chinese partner organisation-which needs to be officially sanctioned, for instance the official trade union, a university, or an NGO with a regular registration as a social organisationand the public security authorities. This will inevitably lead to a closer scrutiny of the local partner by the police organs. Given the fact that most Chinese NGOs, especially in politically sensitive fields, cannot register as social organisations, the restrictions imposed by Article 32 of the Law make it almost impossible for international entities to fund most local NGOs, severely curtailing the ability of local civil society organisations to access foreign funding and putting even more pressure on Chinese activists (as highlighted by the quote which we added at the beginning of this compendium). The parameters for renewing a one-year permit for temporary activity remain unclear and it is not clarified whether multiple temporary activities can be carried out either simultaneously or in subsequent years.

\section{Can a foreign NGO establish more than one office in Mainland China?}

The Law establishes that the representative office of a foreign NGO in China can carry out activities only within their registered operational scope and region, and it cannot establish branch organisations within China, except as otherwise provided by the State Council (Art. 18).

\section{Be aware that:}

Prohibiting the establishment of branches and restricting the work of NGOs only within their registered region impose very serious operational limitations on the type and scope of activities that can be carried out. This provision has the potential to limit multiple 
partners' co-operation and diversification of activities. The option for approval by the State Council is left extremely vague and it remains completely unclear what the scope and significance of exception might entail.

\section{What are the planning and reporting requirements?}

There are two types of reports that a representative office has to submit annually to the Chinese authorities: an activity plan and an annual work report. First, the NGO representative office is required to submit to the Professional Supervisory Unit before the end of each calendar year an activity plan for the following year, including a description of project implementation, use of funds, and other similar content (Art. 19). Within ten days of approval, the representative office has to file the plan with the public security authorities (Art. 19). When variations of the activity plan are necessary, these must be promptly filed with the public security authorities (Art. 19). Second, foreign NGO representative offices are required to file annual work reports to Professional Supervisory Units before 31 January each year (Art. 31). These reports shall include content such as audited financial accounting reports, and reports on the situation of activities, as well as personnel or institutional changes (Art. 31). When dealing with 'temporary activities', foreign NGOs must send written reports to the public security authorities within thirty days of concluding temporary activities. These reports must include information on the state of activities and the use of funds (Art. 30).

\section{Be aware that:}

While planning and reporting are very reasonable requirements for an NGO to operate legally, the Law however is fairly vague on the level of detail required by the annual plan. It is unclear the extent to which such planning will allow a degree of flexibility for the implementation of ad hoc activities or activities in an emergency situation. In case of both temporary and planned activities, it remains unclear how reports will be used, whether they will be simply filed by the relevant authorities or whether they will constitute the basis for approving future activities by the same NGOs.

\section{What funds can be used to support activities within Mainland China?}

The Law explains that foreign NGOs are allowed to use the following funding: a) funds from lawful sources outside of Mainland China; b) interests on bank deposits within Mainland China; and c) other funds lawfully obtained within Mainland China (Art. 21). Foreign NGOs and their representative offices must not fundraise within Mainland China (Art. 21). These funds-which must be used only in accordance with the registered scope of operations (Art. 23)-must be deposited in the bank account that is recorded on the official registration documents or, in the case of temporary activities, the bank account of the Chinese partner unit (Art. 22). Any other strategy to receive funding from abroad is explicitly forbidden (Art. 22) and wire transfers will have to be used in accordance with China's relevant provisions on regulation of foreign exchanges and payments (Art. 25).

\section{Be aware that:}

While these provisions might have been thought of as a way to control illegal money movements from outside and within China, they however present some contradictions and limitations. Article 21 allows for funding to be obtained within Mainland China but excludes the possibility of fundraising within the country. As the activity of fundraising is not defined in this Law, it potentially excludes a significant portion of funding that could come from within the country. It also creates opportunities for funding obtained lawfully to be considered illegal because it is attained through alleged fundraising. The Law also 
excludes the possibility, or makes it extremely difficult, for Chinese citizens to donate to foreign NGOs operating in China, closing avenues for China's wealthy to contribute to international philanthropy.

\section{What about accounting and taxes?}

According to the Law, foreign NGO representative offices are required to implement China's unified accounting system, hiring accountants with Chinese professional certifications to carry out their accounting (Art. 24). Mainland Chinese accounting firms are required to audit foreign NGOs' financial accounting reports (Art. 24). Tax registration, tax declarations, and payment of taxes must be dealt with in accordance with the law (Art. 26), but it is explicitly stated that foreign NGO representative offices enjoy tax and other policy benefits according to the law (Art. 36).

\section{Be aware that:}

There are at least two main problematic issues concerning the required system of accounting and taxes. In terms of accounting, foreign NGOs are financially accountable to their donors, which generally impose strict accounting reporting standards. The imposition of carrying out accounting within China according to China's unified accounting system may either benefit the process of accounting for international donors, or hinder the process if the two systems are completely different, imposing significant operational burdens on the foreign NGOs. The requirements concerning taxes are utterly vague. It remains unclear what taxation regime will apply to foreign NGOs and what benefits, if any, they could potentially enjoy. It is also left unspecified whether these accounting requirements and taxes provisions apply to foreign NGOs conducting temporary activities.

\section{Who should staff a representative office?}

The Law states that foreign NGO representative offices can hire employees in Mainland China as long as they follow local laws and administrative regulations, and that all the information regarding employed personnel must be reported to the professional supervisory units and to the public security organs (Art. 27). Representative offices can designate a chief representative and up to three representatives as required for operations, but they must not be: a) persons lacking or having limited civil capacity; b) persons with a criminal record; c) chief representatives or representatives of representative offices that have been deregistered or had registration certificates cancelled within the past five years; d) other situations provided by the law or regulations (Art. 29). As for the expatriate staff, the Law provides that the chief representative and other representatives that are foreign employees of foreign NGO representative offices may use the organisation's registration certificate, documents proving the representative's status, and other materials to process employment and work permits in accordance with the law' (Art. 38).

\section{Be aware that:}

The clause 'other situations provided by the law or regulations' included in Article 29 is extremely vague and may be broadly interpreted by the public security authorities to exclude anybody who is deemed inadequate according to undefined standards. The Law is also silent in relation to the conditions for hiring volunteers.

\section{What does supervision and management by the Chinese relevant authorities entail?}

The Law provides that public security authorities are not only responsible for the registration of the NGOs' representative offices, annual inspections and the filing of 
temporary activities, but they have also a duty to investigate and punish illegal activities carried out by foreign NGOs. When public security organs suspect that a foreign NGO is violating this Law, they may adopt the following measures: a) question the chief representative and other responsible persons from the foreign NGO representative offices; b) enter the foreign NGOs' domicile and venues of activities within Mainland China to conduct on-site inspections; c) question units and individuals related to the investigation, and request an explanation; d) examine and reproduce documents or materials related to the matters being investigated, and seal documents or materials that might be removed, destroyed, concealed or tampered with; e) seal or seize venues, facilities, or assets suspected of being involved in illegal activities (Art. 41). Public security organs can also make inquiries into bank accounts of units or individuals related to the matter being investigated and request the courts to freeze bank account funds in accordance with the Criminal Procedure Law (Art. 42). Other departments, such as those for national security, foreign affairs, finance, financial oversight, customs, tax, and foreign experts are to conduct oversight and management of foreign NGOs and their representative offices in accordance with the scope of their duties and relevant laws (Art. 43). The anti-money laundering departments shall supervise and manage the opening and use of bank accounts by foreign NGOs, Chinese partner units, and also of units or individuals in Mainland China who receive funds from foreign NGOs (Art. 44).

\section{Be aware that:}

It appears that while the Law is fairly specific on what the public security authorities and other departments can do in case of suspicious activities, it imposes very few limitations on their actions. For example, on the basis of a simple suspicion, the public security can indiscriminately get access to individuals, their properties and domiciles without any significance restriction been imposed by the Law.

What are the penalties for non-compliance?

If a foreign NGO representative office or a foreign NGO carrying out temporary activities in China do not comply with the clauses that govern registration, filing, scope of activities, funds, reporting, supervision and inspection, they and the Chinese partner units will be given warnings or ordered to suspend activities for a given period by the public security organs, have illegal assets or unlawful gains confiscated; where the circumstances are considered serious, their registration certificate or temporary activity permit documents will also be withdrawn by the registration management organs and the temporary activities shut down (Art. 45). The same penalty applies where the representative offices of a foreign NGO, a foreign NGO carrying out temporary activities, or a Chinese partner unit provide false information to obtain registration certificates for representative offices or to obtain an authorisation to carry out temporary activities; or where there are acts of counterfeiting, altering, buying and selling, renting, or loaning registration certificates or seals (Art. 45). NGOs that have been de-registered cannot re-apply to set up representative offices in Mainland China or carry out temporary activities for five years from the date of de-registration, cancellation, or closure (Art. 48).

Article 46 explains that in circumstances where NGOs carry out activities without registration or filing, the public security organs can stop their activities, confiscate their illegally obtained property and unlawful gains, give directly responsible personnel warnings, and, in serious circumstances, detain them for up to ten days (Art. 46). The same applies to circumstances where units and individuals in Mainland China know that a foreign NGO has not registered or filed for 
temporary activities, and co-operate with them or accept their retention or funding, or act as their agent or covert agent to carry out activities for them or accept and spend funds for a project (Art. 46).

More serious penalties are provide for those foreign NGOs and foreign NGO representative offices that: a) incite resistance to the implementation of laws and regulations; b) illegally obtain state secrets; c) create rumours, engage in defamation, or the publication or dissemination of other harmful information that endangers state security or damages the national interest; d) engage in or funding political activities or illegal religious activities; e) other situations that endanger state security or damage the national or public interest (Art. 47). In such circumstances, the public security organs should cancel their registration certificates or shut down temporary activities; where a crime is not constituted, they will detain the persons who are directly in charge and other directly responsible personnel for up to fifteen days; and where a crime is constituted, criminal responsibility is pursued in accordance with the law (Art. 47). The same applies where foreign NGOs or foreign NGO representative offices exhibit criminal conduct such as separatism, undermining national unity, or subverting national sovereignty (Art. 47). These organisations may be added to an unwelcome list by the public security department under the State Council and must not again establish representative offices or carry out temporary activities within Mainland China (Art. 48).

When foreign persons violate this law, relevant organs may lawfully order them to leave the country within a given period of time, deport them, or expel them (Art. 50).

\section{Be aware that:}

Besides including a number ofvery vague clauses that can be easily used to justify arbitrary actions by the public security authorities in the name of protecting social order and stability-for instance, the publication of any critical report can be easily considered as 'dissemination of harmful information'-one problem that emerges from these provisions relates to the use of administrative detention for the personnel of foreign NGOs for up to fifteen days. It is well known that the public security authorities generally implement administrative detention without any judicial supervision and is in strict contrast with international fair trial standards. 
This text is taken from Disturbances in Heaven: A Year of Chinese Labour, Civil Society, and Rights, Made in China Yearbook 2016, edited by Ivan Franceschini, Kevin Lin and Nicholas Loubere, published 2017 by ANU Press, The Australian National University, Canberra, Australia. 